\title{
Disagreement Strategies Used in Jordanian Arabic
}

\author{
Bilal Alkheder, Fawwaz Al-Abed Al-Haq \\ Yarmouk University, Irbid, Jordan
}

\begin{abstract}
This study aims at investigating the disagreement strategies that are usually used by Jordanian Arabic speakers. A discourse completion task (DCT) was used to collect data. The DCT is a written questionnaire that includes 10 imaginary situations. Two thousand three hundred and twenty-two expressions of disagreement were collected from the responses of 217 Jordanian respondents from Yarmouk University in Irbid Governorate. The researcher developed a taxonomy of disagreement strategies to classify the collected data. The findings revealed that Jordanian Arabic speakers employed 11 strategies which fall into two types: softened strategies and strong strategies. In general, Jordanian Arabic speakers prefer to use softened disagreement strategies more than strong strategies. The findings indicated that giving explanations was the most frequently used disagreement strategy, while giving advice was the least used strategy.
\end{abstract}

Keywords: disagreement strategies, Jordanian Arabic, mitigating strategies, strong strategies, giving explanations

\section{Introduction}

Human beings need to communicate with each other. The use of language enables individuals to communicate their ideas and needs. When people exchange a variety of ideas and beliefs, they may agree with some ones and disagree with others. Disagreement is a complex issue in our life. According to Edstrom (2004, p. 1505), the concept of disagreement refers to the "communication of an opinion or belief contrary to the view expressed by the previous speaker". Koczogh (2013, p. 220) defined verbal disagreement as "a situated activity whose function is to express an opinion (or belief) the propositional content or illocutionary force of which is-or is intended to be-partly or fully inconsistent with that of a prior (non-verbal) utterance".

To express disagreement is not only a matter of expressing abstract attitudes and opinions, but also it is a skill that not all people have. It helps to explore more about the social side of human beings' communication. Disagreement is described as "dispreferred action" because it is a face threatening act (Liddicoat, 2007, p. 111). That is why people seek agreement and tend to avoid disagreement. On the other hand, Sifianou (2012) believed that disagreement is not by itself self-threatening and context is not static or simple; rather, it is the context which makes disagreement face threatening or enhancing.

Disagreement can be expressed through some expressions that include attacking another's position, actively defending one's opinion, or quietly withholding approval. Such expressions can "stifle a conversation" by offending an interlocutor (Edstrom, 2004, p. 1499).

Bilal Alkheder, MA in Linguistics, Department of English Language and Literature, Yarmouk University, Irbid, Jordan. bilalalkheder@gmail.com

Fawwaz Al-Abed Al-Haq, Ph. D in linguistics, professor, Department of English Language and Literature, Yarmouk University, Irbid, Jordan.fawazm57@gmail.com 


\section{Problem, Purpose, and Question of the Study}

Since disagreement seems unavoidable and problematic in any society, many researchers analyze disagreement (Sornig, 1977; Muntigl \& Turnbull, 1998; Rees-Miller, 2000; Edstrom, 2004; Chen, 2006; Johnson, 2006; Lawson, 2009; Kakava, 2012; Sifianou, 2012; Bakry, 2015). Thus, disagreement deserves investigation to gain a better understanding of this issue. Thereby, the problems resulted from the use of inappropriate expressions of disagreement can be avoided.

In general, recent studies relating to the expressions of disagreement used by Arabic speakers are particularly rare. To the best knowledge of the researcher, there appears to be an absence of the studies which investigate the disagreement strategies used in Jordanian Arabic. So, the present study partially fills this gap in literature, addressing the disagreement strategies used by Jordanian Arabic speakers. This study aims to explore the following research question: What are the most preferred strategies of disagreement in Jordanian Arabic?

\section{Significance of the Study}

The significance of the study derives from the fact that it is the first study that tries to investigate the disagreement strategies used by Jordanian Arabic speakers since this phenomenon is not investigated in Jordan. So, this study may be a new contribution to the field of pragmatics. Jordanian society is affected by Islamic and Arab culture. To express disagreement is not only to express some contrasting ideas and opinions but also to show one's culture. So, this study tries to discover something about Jordanian Arab culture with respect to the speech act of disagreement. Thereby, such a study reinforces the knowledge of Arabic speakers, students of linguistics, and speakers of other languages concerning the use of disagreement strategies in Jordanian Arabic.

\section{Limitations of the Study}

The present study has the following limitations:

1. All of the respondents of the DCT were students at Yarmouk University in Irbid. So, the findings of the study are limited to this Jordanian region.

2. The researcher depends on Maíz-Arévalo's (2014) taxonomy of disagreement strategies to classify and analyze the gathered data. So, other taxonomies may yield different results.

\section{Literature Review}

Disagreement has been examined by some studies in different languages and from different perspectives. Some studies were conducted to provide a good taxonomy of disagreement strategies. Others investigated the impact of social variables on the choice of disagreement expressions (i.e., gender, social status, and distance). In addition, disagreement was investigated by cross-cultural studies. Other studies investigated variations in the use of disagreement strategies by speakers of English as a Foreign and Second Language.

Muntigl and Turnbull (1998) provided four major disagreement strategies: irrelevancy claims, challenge strategy, counterclaims, and contradiction strategies. Irrelevancy claims refer to the disagreement strategy in which the speaker claims that the interlocutor's statement is irrelevant to the present discussion. In contradiction strategies, the speaker performs an opposed statement to the interlocutor's. This is usually preceded by negations or opposition markers, such as "no, I disagree", "I do not agree", "not at all", "I do not think so", etc. Another strategy to express disagreement is a challenge, when the speaker uses interrogative words (e.g., when, where, what, why, who, and how). Counterclaims are the strategies in which the speaker expresses token or partial agreement, using the pattern "yes, but...". The counterclaims can be used to 
indirectly disagree with the interlocutor by agreeing with the other interlocutor to minimize the face threatening acts and then followed by the speaker's different claim. Muntigl and Turnbull (1998) stated that counterclaims are the least face threatening strategies since they are initiated by mitigating devices, such as hedges.

Rees-Miller (2000) proposed a good classification of disagreement strategies based on Brown and Levinson's (1987) theory of politeness, paying particular attention to ranking and power differences. This taxonomy includes three types of disagreement: softened disagreement, unmodified disagreement (equivalent to Pomerantz's [1984] strong disagreement without any mitigation at all), and aggravated disagreement. Aggravated disagreement is typical of conflicting discourse. Softened disagreement, as described by Rees-Miller (2000), is further divided into positive politeness which includes the linguistic markers that show solidarity (i.e., humor, positive comments, and partial agreement) and negative politeness strategies like the use of questions, or the verbs of uncertainty. Unmodified disagreement includes contradictory statements which are neither softened nor strengthened disagreement. The last type is aggravated disagreement which is done through rhetorical questions, negative judgments, and intensifiers.

Kreutel (2007) proposed a new taxonomy of disagreement expressions employed by non-native speakers of English. Actually, she establishes the following taxonomy (p. 326):

1. Desirable features:

a. Token agreement;

b. Hedges;

c. Requests for clarifications;

d. Explanations;

e. Expressions of regret;

f. Positive remarks;

g. Suggestions.

2. Undesirable features:

a. Message abandonment;

b. Total lack of mitigation;

c. Use of the performative "I disagree";

d. Use of the performative negation "I do not agree";

e. Use of the bare exclamation "no";

f. Blunt statement of the opposite.

The findings demonstrated that learners of English as a second language tended to use the following undesirable strategies: abandonment of the message, use of the performative "I disagree", lack of mitigation, bare exclamation of "no", and blunt statements of the opposite.

Maíz-Arévalo (2014) investigated how the speech act of disagreement is performed by students of English as a lingua franca. Disagreement expressions were classified according to two main categories: strong and weak (mitigated) disagreement (Pomerantz, 1984; Rees-Miller, 2000; Kreutel, 2007). The findings demonstrated that students generally show a tendency to avoid strong disagreement while favoring mitigated disagreement of different types (e.g., expressing uncertainty, advice/suggestion asking for clarification, giving explanations).

As noticed, the previous studies found that the performance of the speech act of disagreement apparently differs from one culture to another. Thus, the choice of disagreement strategies is affected by culture. Moreover, 
the reviewed studies presented different categories of disagreement strategies and guided the researcher to follow the appropriate methodology throughout the present study.

In general, recent studies relating to the expressions of disagreement used by Arabic speakers are particularly rare. To the best knowledge of the researcher, there appears to be an absence of the studies which investigate the disagreement strategies used in Jordanian Arabic. So, the present study partially fills this gap in literature, addressing the disagreement strategies used by Jordanian Arabic speakers.

\section{Method and Procedures}

In this section, the researcher explains the methodology he follows in the present study.

\section{Population and Sample of the Study}

The population of the intended study to which the findings are generalized includes all Jordanian Arabic speakers who live in Irbid Governorate. The sample of the present study includes 217 Jordanian Arabic respondents from Irbid. All of the respondents are students at Yarmouk University in Irbid Governorate.

\section{Data Collection and Procedures}

The data collection instrument adopted for the present study is a written discourse completion task (henceforth DCT). The DCT is a questionnaire composed of some imaginary situations in which the respondents of the study are required to write the response of the given situation (Varghese \& Billmyer, 1996). The DCT which is first adapted by Blum-Kulka (1982) is considered to be an appropriate instrument to collect data in pragmatic studies. The questionnaire used in the present study involved written instructions to the respondents followed by 10 situations that vary in terms of two social variables: "social status" and "social distance" between the interlocutors.

The respondents were requested to write what they would say to show their disagreement in each described situation. The questionnaires were distributed to some students at Yarmouk University in Irbid. The respondents voluntarily responded to the questionnaire which took them about 10 minutes to complete. The researcher also told them that the elicited data will be used for the purpose of the study under investigation.

The researcher believes that the used DCT would be an appropriate research instrument to catch the disagreement strategies. The questionnaire was given to 10 students of linguistics at Yarmouk University as a pilot study to identify any weaknesses and shortcomings of the questionnaire and to ensure its reliability. The 10 respondents finished the questionnaires without facing any difficulties and they expressed disagreement in each situation. The pilot study proved to be successful. Thereby, the research instrument is reliable.

\section{Data Analysis}

The responses of the respondents were manipulated and categorized in order to extract disagreement strategies. When analyzing the collected data, the researcher found only two irrelevant responses in which the students expressed their agreement instead of expressing disagreement and five incomplete responses. Thus, these responses were excluded, for the purpose of the present study. To analyze the gathered data, the researcher developed Maíz-Arévalo's (2014) taxonomy of disagreement strategies. The disagreement strategies were then counted and their percentages were also taken. In addition, the researcher explains each disagreement strategy, giving some examples. 


\section{Findings and Discussions}

The primary objective of this study is to examine Jordanian Arabic speakers' production of the speech act of disagreement. The researcher categorized the collected data into 11 disagreement strategies. Then, the occurrences of the identified strategies and their percentages were shown. All of the identified strategies were discussed with ample examples given by the respondents of the DCT (see Appendix III which includes additional expressions of disagreement).

According to Maíz-Arévalo (2014), the disagreement strategies generally fall into two main types: strong and weak (softened) strategies. Strong disagreement is characterized by the lack of mitigation of any sort. Furthermore, the speaker is concerned with defending his/her claims more than considering the hearer's desires. As opposed to strong disagreement, weak disagreement is characterized by the use of linguistic elements that minimize the face-threat of disagreement (p. 209). Strong disagreement includes "giving explanations", "partial agreement/positive remarks", "expressions of uncertainty", "statement of regret", and "giving advice". Weak disagreement includes "bare negative forms", "blunt statements of the opposite", "insults/negative judgments", "swearing", and "stating disagreement". Table 1 presents the identified disagreement strategies, the number of occurrences of the strategies, and their percentages.

Table 1

Disagreement Strategies

\begin{tabular}{llll}
\hline No. & Disagreement strategies & No. of occurrences & Percentage (\%) \\
\hline 1 & Giving explanations & 497 & 21.23 \\
2 & Bare negative forms & 402 & 17.31 \\
3 & Blunt statement of the opposite & 340 & 14.64 \\
4 & Partial agreement/positive remarks & 305 & 13.13 \\
5 & Expressions of uncertainty & 202 & 8.69 \\
6 & Insults and negative judgments & 182 & 7.83 \\
7 & Requests for information/clarification & 166 & 7.14 \\
8 & Swearing & 133 & 5.72 \\
9 & Stating disagreement & 51 & 2.19 \\
10 & Statements of regret & 25 & 1.07 \\
11 & Giving advice & 19 & 0.81 \\
\hline Total & & 2,322 & 100 \\
\hline
\end{tabular}

Obviously, Table 1 displays that the respondents used 11 strategies: giving explanations, bare negative forms, blunt statements of the opposite, partial agreement/positive remarks, expressions of uncertainty, insults and negative judgments, requests for information/clarification, swearing, stating disagreement, statements of regret, and giving advice. In addition, the respondents employed 2,322 disagreement instances.

As noticed, the disagreement strategies have different frequencies. The strategies are listed in order of preference (from the most to the least preferred strategy). The most striking feature of Table 1 is that the respondents tend to use four strategies more than the other ones: giving explanations, bare negative forms, blunt statements of the opposite, and partial agreement/positive remarks. The most frequently used strategy was giving explanations, which was used on 497 occasions (21.23\%). The second most frequently used strategy was the bare negative forms. This strategy was used on 402 occasions (17.31\%). In addition, blunt statements of the opposite were employed on 340 occasions (14.64\%) while partial agreement/positive remarks on 305 occasions 
(13.13\%). The least used strategies were stating disagreement employed 51 times (2.19), statements of regret 25 times (1.07\%), and giving advice 19 times (0.81).

\section{Giving Explanations}

Jordanian speakers give explanations as the most preferred strategy $(21.23 \%)$ when they perform the speech act of disagreement. When the speaker performs the speech act of disagreement, he/she explains and justifies his/her ideas through giving some reasons, examples, and details in order to support his/her opposition (Lawson, 2009). As known, the speech act of disagreement itself is a face threatening act. The direct disagreement "I disagree with you", for example, without providing any softening devices (i.e., explanations) may threaten the hearer's positive face. So, the speaker gives explanations because of his/her intention to soften the illocutionary force of disagreement on the hearer (Bakry, 2015). Consider the following examples:

أنا ما بتفق معك , لانه الجو بكون حامى في الصيف (1)

I do not agree with you, because it is hot in summer. Situation (4)

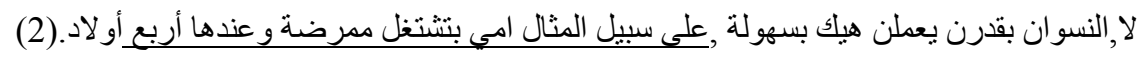

No, women can easily do that. For example, my mother works as a nurse, and she has four children. Situation (3)

مش صحيح, لأنه الجو بكون حامى فى الصيف (3) (3) (3) (3)

Not true, because summer is hot. Situation (9)

As noticed, the speakers used the underlined expressions as their justifications for why they disagree with the hearer. The use of explanations is considered to be one of the positive politeness strategies (Brown \& Levinsons, 1987). In the above examples, the speakers try to preserve the hearer's positive face and to give $\mathrm{him} /$ her the right to clear misunderstandings. Thereby, the speakers express their opposing opinions in a more polite and convincing way. The use of explanations is considered to be one of the most preferred strategies in a number of studies on disagreement (Kreutel, 2007; Lawson, 2009; Fernandez, 2013; Maíz-Arévalo, 2014).

\section{Bare Negative Forms}

The second most preferred strategy for the respondents of the present study was the use of bare negative forms. This strategy represents $17.31 \%$ of the used disagreement strategies. According to Muntigl and Turnbull (1998), the speaker uses the negative particle "no" as a way to express his/her explicit opposition to the hearer's claim. Consider the following examples:

(4) لا, مش صحيح

No, not true. Situation (8)

(5)

Of course not. Situation (10)

كلامك مش صحيح (6)

What you say is not true. Situation (6)

In the examples above, the speakers express their strong denial to what the hearer said, using the underlined expressions that contain negative forms. The use of negative forms is a straightforward way to express disagreement, and this is what Lawson (2009) considered as "unmitigated disagreement". As noticed, there are no attempts on the part of the speakers to lessen the force of disagreement; the speakers are only concerned with expressing their points of view. According to Brown and Levinson (1987, p. 214), the use of contradictions belongs to off-record strategies. Using such a strategy, the speakers are only interested in 
refuting the previous opinions. In Maíz-Arévalo's (2014) taxonomy, the use of bare negative forms is a strong disagreement strategy which is characterized by the lack of mitigation of any sort.

\section{Blunt Statement of the Opposite}

Another preferred strategy is the statement of the opposite delivered in a blunt manner. This strategy represents $14.64 \%$ of the total occurrences. It is the third most frequent strategy used by the respondents of the present study. The examples below illustrate the use of this strategy:

مش صحيح ,النسو ان بقدرن يجمعن بين الثغل و مسؤولياتهن العائلية (7) مانسان

Not true. Women are able to combine work and their family commitments. Situation (8)

الأدب ممتع جدا (8)

Literature is very interesting. Situation (5)

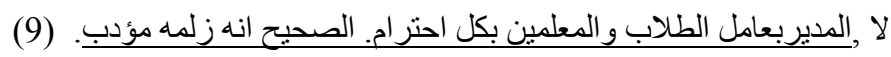

No, the principal treats students and teachers with more respect. In fact, he is a polite man. Situation (2)

In these examples, the underlined expressions are blunt statements of the opposite. Such a strategy is employed by the speakers to show their rejection of previous opinions and to correct the hearer. The speakers noticeably expressed their opposing opinions in a blunt manner as a way to strengthen their disagreement, neglecting the hearer's desires. So, blunt statements of the opposite belong to strong disagreement strategies (Maíz-Arévalo, 2014)

\section{Partial Agreement/Positive Remarks}

Some expressions of disagreement were prefaced with statements of agreement or positive remarks towards the hearer or what he/she says. The examples below illustrate how Jordanian Arabic speakers employed this strategy:

(10). آهربس انا بشوف انه النسوان في مجتمعنا بكونن مبسوطات أكثر لما يكونن أمهات و بشتنلغن

Yes, but I see that women in our society feel very happy of being working mothers. Situation (3)

معاك حق, لكن الثتاء ممتع أكثر من الصيف . (11)

You are right, but winter is more interesting than summer. Situation (7)

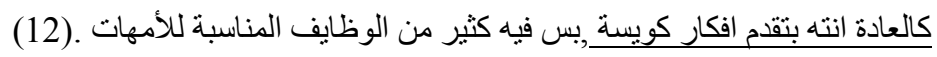

As usual, you present good ideas, but there are many suitable jobs for mothers. Situation (8)

In these examples, the speakers first employed the underlined statements of agreement and positive remarks, like "yes", "you present good ideas as usual", "you are right", and "I agree with you", as a way to appreciate a previous opinion and to show respect towards the hearer. Then, the speakers expressed their opposing statements prefaced with the contrastive marker "بس"; the "but-statement" is written in italics. Obviously, the respondents expressed their opposition through the following pattern: "positive remark or agreement + but-statement".

In terms of politeness theory, partial agreements/positive remarks are positive politeness strategies that are used to hide/lessen the force disagreement (Brown \& Levinson, 1987). Disagreement is prefaced with statements of agreement as an indirect strategy to soften the force of disagreement. In his taxonomy of disagreement expressions, Kreutel (2007) considered partial agreement and positive remarks as "desirable features". So, this strategy is the most polite and appropriate strategy to express disagreement by the respondents of the present study; thereby, it is a weak disagreement strategy. 
This strategy was employed on 305 occasions and it represents $13.13 \%$ of the total occurrences of the 11 strategies. Partial agreement and positive remarks were frequently employed by Jordanian Arabic speakers. This finding is inconsistent with the findings of some previous studies (Kreutel, 2007; Lawson, 2009) that demonstrated that partial agreement was one of the least used strategies.

\section{Expressions of Uncertainty}

This strategy represents $8.69 \%$ of the total occurrences. In these expressions, the speaker implies that he/she is not completely certain about what he/she claims. The use of uncertainty expressions is a weak disagreement strategy. Consider the following examples:

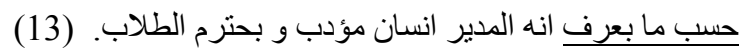

As far as I can see, the principal is a polite person and respects students. Situation (2)

الحقيقة إني ما بعرف بس ما أظن انه فصل الصيف رائع دايما. (14)

In fact, $\underline{I}$ do not know. I do not think that summer is always interesting. Situation (9)

بجوز. بالنسبة إلي, أني أحيانا بحس انه الثتاء أحسن بكثير من الصيف. (15)

Maybe. To me, I sometimes feel that winter is much better than summer. Situation (5)

In these examples, the use of the underlined linguistic devices shows that the speakers are not sure about their opposing claims. These devices are intentionally used to lessen the force of disagreement on the hearer's face (Locher, 2004). Moreover, the use of the underlined expressions implies that the speaker to some extent frees himself/herself from the responsibility of the truth value of the opinion he/she expressed (Koczogh, 2013). Uncertainty expressions enable the speaker to make his/her point of view less direct and perhaps less threatening to the hearer's face. The use of uncertainty expressions by Jordanian Arabic speakers confirms Kreutel's (2007) finding that the expressions like "I think", "I do not think", and "I do not know" are frequently used by native speakers.

\section{Requests for Information/Clarification}

This strategy represents $8.69 \%$ of the total occurrences of the disagreement strategies. In this strategy, the speaker asks the hearer to provide much information and also to justify his/her point of view. Below are some explanatory examples:

أعطي دليل على صحة كلامك. (16)

Present evidence to prove your point. Situation (9)

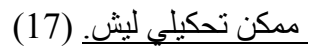

Could you tell me why? Situation (1)

انته ليش بتقول انه الأدب ممل ؟ (18)

Why do you think that literature is boring? Situation (3)

بصر احة انا ما فهمتش بلو انك اتوضح فكر تلك. (19)

I did not really understand. Could you clarify your point? Situation (4)

شوقصدك ؟ (20)

What do you mean by that? Situation (8)

As noticed, the speakers do not directly state their disagreement in these examples. Instead, the respondents asked for further information. So, disagreement is implicitly performed via the use of another speech act, a request. The reason for using such a strategy is that the speaker sometimes wants to show disagreement, but he/she is unable to provide a different point of view. In this regard, Bardovi-Harlig and 
Hartford (1990) argued that asking for further information is used by the speaker as an indirect way to have enough time to plan for their refusals. So, this is another weak indirect strategy used by Jordanian Arabic speakers to express their disagreement.

\section{Insults and Negative Judgments}

This strategy represents $7.83 \%$ of the employed strategies as the seventh frequent strategy. In this strategy, the speaker criticizes, insults, or expresses his negative evaluation or feeling towards the hearer. This strategy is considered to be impolite, inappropriate, and offensive (Koczogh, 2013). The following examples illustrate the use of this strategy:

انت بتحكي هيك لأنك ابتكره المدير. (21)

You said that because you hate the principal. Situation (2)

هذا رأيك انته ,لا تفرضه على. انا مابتفق معك بالمرة. (22)

This is your personal opinion. Do not impose it on me. I do not agree with you at all. Situation (4)

انته مين بتفكر حالك لحتى تحكي هيك؟ (23)

Who do you think you are to say that? Situation (9)

مش شغلك (24) مuت

None of your business. Situation (1)

The underlined expressions show that the speakers employed their negative judgments and insults as indirect strategies in which the speaker attempts to save face by confronting the hearer. Negative judgments and insults are used by the speaker to "strengthen disagreement" (Fernandez, 2013). In addition, the use of such strategies in the context of disagreement shows that the speaker considers defending his/her point of view more important than protecting the hearer's face (Culpeper, 2011). That is to say, the hearer's face is neglected and surely threatened. Thus, this is the most offensive strategy among all of the disagreement strategies employed by the respondents of the present study.

\section{Swearing}

Abd el-Jawad (2000, p. 218) defined swearing as "the speech act by which a person binds himself to do or not to do a certain specific physical or judicial act, by invoking the name of God or one of the divine attributes". Swearing represents $5.72 \%$ of the total occurrences of the used strategies. In the following examples, the opposing opinions were prefaced by swearing expressions:

و واله ما هو صحيح. (25)

I swear to Allah that is not true. Situation (1)

وحياة ربك ما هو صحيح. (26)

By the soul of your God that is not true. Situation (4)

لا , وحياة الله مانته صادق. (27)

No, I swear to Allah that you are wrong. Situation (10)

In these examples, the speakers employed the underlined expressions (swearing by Allah) as a strong strategy of disagreement. In Arab and Islamic culture, swearing supports the utterance of the speaker and gives it more credibility (Al-Batayneh, 2013). Swearing seems to be a new disagreement strategy which was not found in many studies on disagreement. Indeed, the use of swearing is due to the fact that Jordanians belong to Arab Islamic culture (Saed, 2016). So, Jordanian Arabic speakers employ swearing as one of the strong strategies in the context of disagreement in order to support and strengthen their opposing claims. 


\section{Stating Disagreement}

What Koczogh (2013) termed stating disagreement was one of the least frequently employed strategy $(2.19 \%)$ by the respondents of the present study. In this strategy, the speaker explicitly states his disagreement with the hearer. For clarification, consider the following examples:

لا, أنا بختلف معك. (28)

No, I disagree with you. Situation (1)

أنا ما بتفق معك في هاي النقطة. (29)

I do not agree with you about this point. Situation (9)

The examples above show that the speakers use the performatives " disagreement explicitly. Stating disagreement is a direct strategy in which the speaker uses the performatives "disagree" and "not agree" (Koczogh, 2013). So, this is a straightforward disagreement strategy in which the speaker does not try to soften the perlocutionary force of the utterance on the hearer. As a result, stating disagreement is described as a strong disagreement strategy. Once again, stating disagreement was one of the least used strategies in the present study. This finding is in line with Pearson (1986) and Beebe \& Takahashi (1989), in which they emphasize that native speakers rarely use the performative "I disagree".

\section{Statements of Regret}

Disagreement was accompanied with statements of regret in some instances. According to Brown and Levinson (1987, p. 131), statements of apologizing or regret are negative politeness strategies (linguistic devices that aim to create distance between the speaker and the hearer). Statements of regret were rarely used by the respondents of the present study. Consider the following examples:

آسف, بس أنا بشوف انك ما حكيت الحقيقة. (30)

I am sorry, but I see you did not say the truth. Situation (3)

بتأسف منأك كثير, بس أنا ما بتفق معك في هاي النقطة. (31)

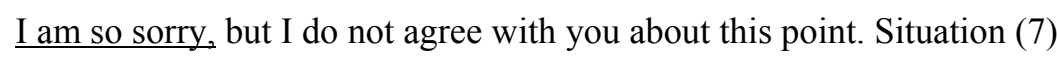

المعزرة منك, هذا مش صحيح . (32)

Excuse me, that is not true. Situation (8)

In these examples, we can observe a combination of two strategies (regret and another strategy). In the last example, the speaker first uses the underlined statement of regret, "المعذرة_ (Excuse me)" and then the other expression, "هذا مش صحيح (that is not true)" which contains a negative form. Statements of regret minimize the face-threatening nature of the speech act of disagreement, as also happens with other speech acts like refusals (Al-Khatib, 2006). Expressions of regret were characterized as desirable features in Kreutel's (2007) taxonomy. But the respondent of the present study rarely used this strategy. The respondents used expressions of regret on only 25 occasions (1.07\%). This is one of the least used strategies by the respondents of the present study.

\section{Giving Advice}

Giving advice was the least used strategy by Jordanian Arabic speakers. It was employed on only 19 occasions (0.81\%). Advisory verbs (i.e., advise, caution, propose, recommend, and suggest) fulfill the communicative goal of causing the hearer to carry out a specific action because the action benefits the hearer (Bach \& Harnish, 1979, 48). In this regard, when the speaker gives a piece of advice, he/she shows that he/she thinks that the hearer should do some act exclusively for his/her benefit. Consider the following examples: 
بنصحك تفهم الادب كويس. (33)

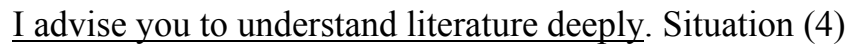

اقر أ روايات وشعر ورح تثوف انه معي حق. (34)

Read novels and poetry; then, you will see that I am right. Situation (5)

انا شايف انك بتكره الددير. حاول انك تحسن علاقتلك بيء. (35)

I see that you hate the principal. Try to improve your relationship with him. Situation (2)

لا تحكمش على الناس من مظاهر ها. هاب نصيحتى اللك. (36)

Do not judge people by their appearance. That is my own advice for you. Situation (2)

In the examples above, the speakers implicitly expressed their opposing opinions by employing the underlined expressions. In other words, disagreement is presented in the advice-giving form. The addressee can interpret the underlined expressions as opposing opinions.

The use of this indirect form of disagreement by Jordanians as a disagreement strategy is more polite than using some strong explicit expressions (e.g., no, not true). Lin (2005, p. 147) argued that advice is employed to shorten the social distance between the speaker and the hearer. In addition, Bayraktaroglu's (2001) findings indicate that advice-giving in Turkish Islamic culture is employed to consolidate solidarity among interlocutors. In fact, the use of advice by Jordanian Arabic speakers indicates that they are affected by their Arab Islamic culture which values the concept of advice (Saed, 2016). Giving advice seems to be a new strategy that was not presented by many related studies on disagreement. So, the use of advice by Jordanians may be due to the crucial impact of culture.

As noticed, Jordanian Arabic speakers show some variations in the choice of the 11 disagreement strategies. The most frequently used strategies were giving explanations, bare negative forms, blunt statements of the opposite, and partial agreement/positive remarks. On the other hand, the least employed strategies were stating disagreement, statements of regret, and giving advice. All in all, Jordanians tend to use weak disagreement strategies slightly more than strong strategies. In other words, Jordanians generally tend to employ mitigating devices when they disagree with the hearer. These findings are consistent with Brown and Levinson's (1987) principles in that the speakers use politeness strategies in order to decrease the possible threat to the hearer (i.e., to save the hearer's face).

Explanations and reasons were employed on 497 different occasions. Noticeably, Jordanian Arabic speakers frequently give reasons and explanations whether they have close or distant relationships with the hearer. In fact, the researcher agrees with Brown and Levinson (1987) in that this is a polite strategy used by the speaker to reduce the threat on the hearer's face. In addition, explanations and reasons are used as mitigating devices in a number of related studies (Kreutel, 2007; Lawson, 2009; Fernandez, 2013). Giving explanations was the most frequently used strategy by Jordanians. This finding is consistent with the findings of many related studies (Al-Issa, 1998; Al-Shboul, Maros, \& Yasin, 2012; Fernandez, 2013) in which interlocutors give explanations as one of the most preferred strategies.

The findings of the present study also revealed that both swearing and giving advice were used, as disagreement strategies, by Jordanian Arabic speakers. These new strategies were not presented in other related studies on disagreement. The use of swearing and advice in the context of disagreement could reflect the impact of Arab Islamic culture on Jordanians. This finding corresponds to the finding of Saed's (2016) study in which Jordanian Arabic speakers use advice because they are affected by their Arab Islamic culture which values the concept of advice 
Swearing is used by Jordanians as a means for intensifying the effect of disagreement in order to gain a sense of credibility. This finding agrees with the findings of Abd el-Jawad's (2000) study in that the speakers in Muslim and Arab cultures use swearing to convince the hearer of his/her honesty and sincerity about what is being said. Also, Al-Issa (1998) found evidence of frequent reference to God (i.e., swearing by Allah) in the realization of refusals in Jordanian Arabic, which is consistent with the findings of the present study. That is to say, the use of swearing is one of the specific aspects of Jordanian Arabic speakers in their interaction.

\section{Conclusions and Recommendations for Future Research}

This study was conducted to contribute to the existing literature on the speech act of disagreement. The researcher investigated the disagreement strategies used by Jordanian Arabic speakers. Based on the results and the analysis of 2,322 disagreement instances, several conclusions can be drawn.

With regard to question of this study (What are the most preferred strategies of disagreement in Jordanian Arabic?), the findings revealed that Jordanians employed 11 disagreement strategies, and they show some variations in the employment of those strategies. The most frequently employed strategies were giving explanations, bare negative forms, blunt statements of the opposite, and partial agreement/positive remarks. In addition, Jordanians employ expressions of uncertainty, insults/negative judgments, requests for information/clarification, and swearing. The least used strategies were stating disagreement, statements of regret, and giving advice.

In general, Jordanians tend to employ mitigating devices in their disagreement. This is due to the fact that disagreement is a face threatening act. The most frequently used strategy was giving explanations. Jordanian Arabic speakers used this strategy to show great concern to the hearer's face. This finding corresponds to previous findings of some speech act studies in Jordanian Arabic (Al-Issa, 1998; Khwaileh, 2005; Al-Shboul et al., 2012) in that Jordanian Arabic speakers more frequently give explanations in their interaction. The frequent employment of this strategy represents a remarkable feature of the communication style in Jordanian society. In addition, partial agreement was one of the most preferred weak strategies by Jordanian Arabic speakers. This finding corresponds to Maíz-Arévalo's (2014) suggestion that partial agreement is one of those strategies that native speakers most frequently employ. The findings of the present study also revealed that both swearing and giving advice were used as disagreement strategies by Jordanian Arabic speakers. These new strategies were not presented in other related studies on disagreement. Thus, the use of swearing and advice in the context of disagreement reflects the impact of Arab Islamic culture on Jordanians.

The study of disagreement strategies in Jordanian Arabic is still recent. So, the researcher gives the following recommendations in order to have a better understanding of the speech act of disagreement:

1. Future studies on disagreement should investigate the impact of other social factors (i.e., gender and age) that may affect the use of disagreement in Jordanian Arabic.

2. Further research may address the effect of some variables (e.g., age and gender) on the use of disagreement strategies.

3. With regard to cross-cultural studies, the researcher recommends to conduct a contrastive study on disagreement between Jordanian Arabic and another language (i.e., American English) to investigate the similar and different linguistic styles used in two culturally different languages. 


\section{References}

Abd el-Jawad, H. R. (2000). A linguistic and sociopragmatic and cultural study of swearing in Arabic. Language, Culture and Curriculum, 13(2), 217-240.

Al-Batayneh, H. (2013). Implicit compliments in Jordanian Arabic (Unpublished Master thesis, Yarmouk University, Irbid, Jordan).

Al-Issa, A. (1998). Socio-pragmatic transfer in the performance of refusals by Jordanian EFL Learners: Evidence and motivating factors (Unpublished Ph.D. dissertation, University of Pennsylvania, USA).

Al-Khatib, M. A. (2006). The pragmatics of invitation making and acceptance in Jordanian society. Journal of Language and Linguistics, 5, 272-294.

Al-Shboul, Y., Maros, M., \& Yasin, M. S. M. (2012). An intercultural study of refusal strategies in English between Jordanian EFL and Malay ESL postgraduate students. The Southeast Asian Journal of English Language Studies, 18(3), 29-39.

Bach, K., \& Harnish, R. M. (1979). Linguistic communication and speech acts. Cambridge, Mass.: MIT Press.

Bakry, H. T. (2015). The interface of politeness strategies and power relations in disagreements among Egyptian students (Doctoral dissertation, The American University, Cairo).

Bardovi-Harlig, K., \& Hartford, B. S. (1990). Learning to say "no": Native and non-native rejections in English. Paper presented at the Conference on Pragmatics and Language Learning, Urbana-Champaign, IL.

Bayraktaroglu, A. (2001). Advice-giving in Turkish. In A. Bayraktaroglu and M. Sifianou (Eds.), Linguistic politeness across boundaries: The case of Greek and Turkish (pp. 177-208). Amsterdam: Benjamin.

Beebe, L. M., \& Takahashi. T. (1989). Sociolinguistic variation in face-threatening speech acts: Chastisement and Disagreement. In M. R. Eisenstein (Ed.), The dynamic interlanguage: Empirical studies in second language variation (pp. 199-218). New York: Plenum.

Blum-Kulka, S. (1982). Learning to say what you mean in a second language: A study of the speech act performance of Hebrew second language learners. Applied Linguistics, 3(1), 29-59.

Brown, P., \& Levinson, S. C. (1987). Politeness: Some universals in language usage (Vol. 4). Cambridge: Cambridge University Press.

Chen, M. (2006). An interlanguage study of the speech act of disagreement made by Chinese EFL speakers in Taiwan (Unpublished doctoral dissertation, National Sun Yat-Sen University).

Culpeper, J. (2011). Impoliteness: Using language to cause offence. Cambridge: Cambridge University Press.

Edstrom, A. (2004). Expressions of disagreement by Venezuelans in conversation: Reconsidering the influence of culture. Journal of Pragmatics, 36, 1499-1518.

Fernandez, S. (2013). The linguistic realization of disagreements by EFL Egyptian speakers (Unpublished MA thesis, Universidad Complutense, Madrid, Spain). Retrieved from http://eprints.ucm.es/23287/1/Sonia_Shabaka_Fern\%C3\%A1ndez.pdf

Johnson, F. (2006). Agreement and disagreement: A cross-cultural comparison (Unpublished MA thesis, University of London, Birkbeck).

Kakava, C. (1993). Negotiation of disagreement by Greeks in conversations and classroom discourse (Unpublished doctoral dissertation, Georgetown University, Washington, DC).

Koczogh, H. (2013). Scrutinizing the concept of (verbal) disagreement. Argumentum, 9, 211-222.

Kreutel, K. (2007). I'm not agree with you: ESL learner's expressions of disagreements. TESL-EJ, 11(3), 1-35.

Khwaileh, F. (2005). A pragmatic analysis of Jordanian Arabic and American English refusal strategies (Unpublished Master Thesis, Yarmouk University, Irbid, Jordan).

Lawson, A. J. (2009). From the classroom to the bar room: Expressions of disagreement by Japanese speakers of English (Unpublished Master's thesis, University of Birmingham, UK). Retrieved from http://www.birmingham.ac.uk/documents/college-artslaw/cels/essays/matefltesldissertations/lawsondiss.pdf

Liddicot, A. J. (2007). An introduction to conversation analysis. London: Continuum International Publishing Group.

Lin, H. (2005). Contextualizing linguistic politeness in Chinese: A sociopragmatic approach with examples from persuasive sales talk in Taiwan Mandarin (Ph.D. thesis, The Ohio State University, Columbus, USA.)

Locher, M. (2004). Power and politeness in action: Disagreement in oral communication. Berlin; Germany: M. de Gruyter.

Maíz-Arévalo, C. (2014). Expressing disagreement in English as a lingua franca: Whose pragmatic rules? Intercultural Pragmatics, 11(2), 119-224.

Muntigl, P., \& Turnbull, W. (1998). Conversational structure and facework in arguing. Journal of Pragmatics, 29, 225-256. 
Pearson, E. (1986). Agreement/Disagreement: An example of results of discourse analysis applied to the oral English classroom. ITL Review of Applied Linguistics, 74, 47-61.

Pomerantz, A. (1984). Agreeing and disagreeing with assessments: Some features of preferred/dispreferred turn shapes. In J. Maxwell Atkinson and J. Heritage (Eds.), Structures of social action: Studies in conversation analysis (pp. 57-101). Cambridge: Cambridge University Press.

Rees-Miller, J. (2000). Power, severity, and context in disagreement. Journal of Pragmatics, 32(8), 1087-1111.

Saed, S. (2016). Persuasion strategies used by sellers in Jordanian shops (Unpublished Master thesis, Yarmouk University, Irbid, Jordan).

Sifianou, M. (2012). Disagreement, face, and politeness. Journal of Pragmatics, 44(12), 1554-1564.

Sornig, K. (1977). Disagreement and contradiction as communicative acts. Journal of Pragmatics, 1, 347-374.

Varghese, M., \& Billmyer, K. (1996). Investigating the discourse completion tests. Working Paper in Educational Linguistics, 12(1), 39-58. 


\section{Appendix I: DCT Questionnaire}

جامعة اليرموك

كلية الآداب

قسم اللغة الانجليزية و آدابها / اللغويات

الباحث: بلال الخضر

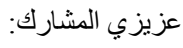

تصميم هذه الاستبانة لاستكثاف استراتيجيات الاختلاف في الر أب المتداولة بين الأردنيين وتأثير المتغيرات الاجتماعية على استخدام تلك الاستر اتجيات. لقد تم

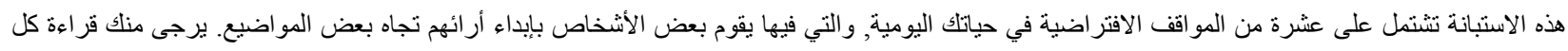
موقف جيدا, وكتابة ما يمكن أن تقوله لإظهار اختلافلك مع تلأك الآراء, مستخدما اللهجة الأردنية.

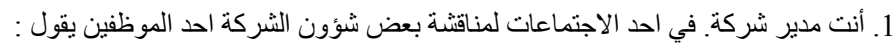

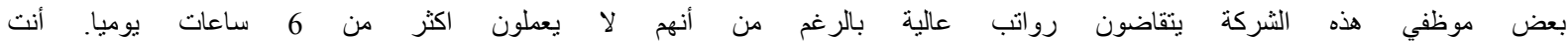
تقول :

2. أنت أستاذ في مدرسة تتحدث مع احد زملائك الأساتذة, الأستاذ يخبرك بأن مدير المدرسة شخص عصبي و لا يحترم الطلاب. أنت تقول:

3. أنت طالب جامعي,أنت تتناقش و أحد أساتذتك في بعض الأمور التي تخص مجتمعك. الدكتور يرى بأنه ليس باستطاعة النساء الجمع بين العمل وتنشئة العائلة .

أنت تقول:

4. أنت وصديقك المقرب تجلسون في الحديقةصديقك يقول:. الصيف هو افضل فصول السنة, في الصيف,يستطيع الناس القيام بأي نثاط يريدون, أنت تقول :

و بعض زملائك في الجامعة تتحدثون عن الأدب .احدهم ممن لا تعرفه سابقا يخبرك بأن الأدب ممل جدا و لا يوجد أي فائدة من دراسته. أنت تقول: 5. أنت

6. أنت موظف في إحدى الشركات. في احد الاجتماعات مع موظفي الشركة. احد زملائك يقول :

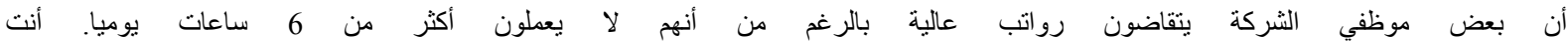

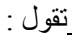

7. أنت طالب في الجامعة تتحدث مع احد أساتنتك, الأستاذ يخبرك بأن الأدب ممل جدا ولا يوجد أي فائدة من دراسته. أنت تقنول :

8. أنت تجلس مع بعض الأشخاص في الحديقة وتتناقثون في بعض المواضيع. احد الأشخاص الغرباء: يقول: الصيف هو أفضل فصول السنة, في الصيف,يستطيع

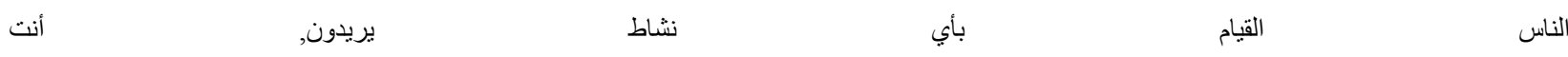
تقول :

9. أنت أستاذ جامعي, انت تناقش بعض المو اضيع التي تخص مجتمعك مع احد الطلاب الذين تدرسهم في الجامعة. الطالب برى بأن المر أة لا تستطيع أن تجمع بين العمل وتنشئة العائلة .

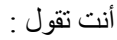

10. أنت تجلس مع صديقلك المقرب في الحديقة. صديقلك المقرب يقول: الأدب ممل جدا و لا يوجد أي فائدة من در استه. أنت تقول: 


\section{Appendix II: DCT Questionnaire}

Yarmouk University

Faculty of Arts

Department of English Language \& Literature

Researcher: Bilal Al-Kheder

Dear participants,

This questionnaire is intended to investigate the disagreement strategies used by Jordanian Arabic speakers and the impact of the social factors on those strategies. The questionnaire includes 10 imaginary situations, in which somebody expresses his/her opinion towards something. Please read these situations and write down your responses, in which you express your disagreement with each opinion, using your everyday Jordanian Arabic.

1. You are the manager of a company. You are discussing some affairs of the company in the meeting with the employees. An employee says: some employees of this company are paid high salaries even though they do not work more than 6 hours a day.

You say:

2. You are a teacher. You are talking with your colleague. He tells you that the school principal is nervous and he does not respect students.

You say:

3. You are a student. You are discussing some affairs about your society with one of your professors. He says that women cannot combine work and their family commitments.

You say:

4. You are sitting in the garden with your close friend. Your friend says that summer is the best season In summer, people can do whatever they like.

You say:

5. You are talking with your classmates about literature. A stranger tells you that literature is so boring and there is no advantage in studying literature. You say:

6. You are an employee in a company. In a meeting with the employees of the company, one of your colleagues sees that some employees are paid high salaries even though they do not work more than 6 hours a day. You say:

7. You are a student. You are talking with one of your professors. He says: literature is so boring and there is no advantage in studying literature. You say:

8. You are sitting with some people in the garden and discussing some topics. A stranger says that summer is the best season In summer, people can do whatever they like. You say:

9. You are a professor. You are discussing some affairs of your society with one of your students. The student says: women cannot combine work and their family commitments.

You say:

10. You are sitting with your close friend in the garden. He says literature is so boring and there is no advantage in studying literature. You say: 


\section{Appendix III: Disagreement Expressions}

No. disagreement strategies

1 Giving explanations

2 Bare negative forms

Linguistic devices

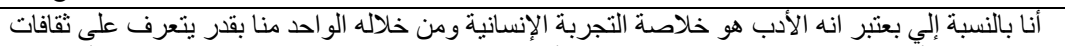

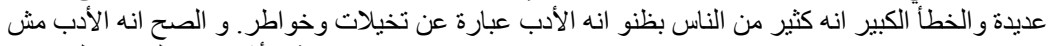

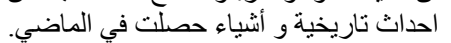

مش صحيح لأنه كل و احد بوخذ اللي بستحقه.

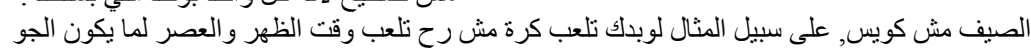

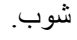

مش صحيح, لأني أنا بعرف المدير من أكثر من 5 سنوات , و أنا عارفه شو هوه.

اكيد لا.

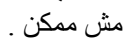

اطلاقا هذا مش صنيح.

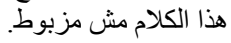

لا لا لا الصح انه مش هيك.

المدير بعامل الطلاب وكأنهم او لاده لاد.

3 Blunt statement of the opposite

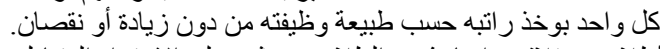

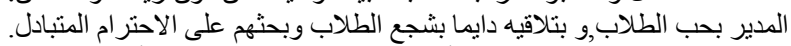

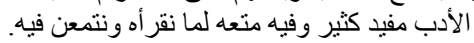

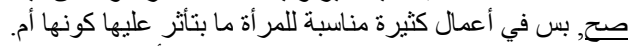

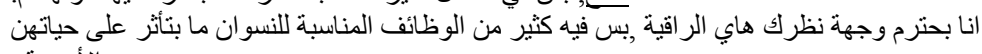

4 Partial agreement/positive remarks

الأسرية.

بجوز,ولكن انا بشوف انه المر أة تسطيع القيام باعمال كثيرة بالإضافة إلى تربية العائلة من دون أي مشاكل.

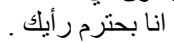

كلام سليه.

هيك مو اضيع مش من السهل انك تعطي فيها حكم قطعي.

ما حد بقدر يحكم مية في المية في هيك مو اضيك التيع.

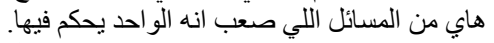

5 Expressions of uncertainty

احتمال

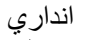

بس مر ات بالصيف الو احد ما بطيق حاله.

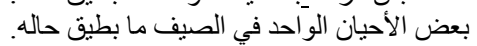

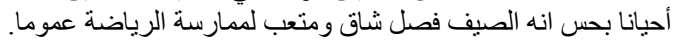

كيف يعني مش فاهمج

6

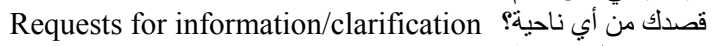

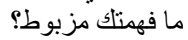

ياغبي, الأدب مش ممل,و الله انته اللي ممل.

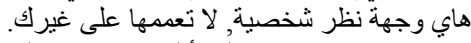

7 Insults and negative judgments

انته بتحكي هيك لأنك حسو د و شكالك.

اللي أنته قلته اسمه حكي فاضك فاضي.

انته هيك بتظلمه للزلمهي.

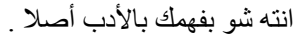

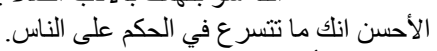

8 Giving advice

لازم تحب الأدب حتى تعرف الهي الهميته لمجتمعنا.

غير طريقة تعاملك مع المدير.

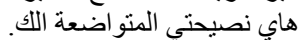

وحياة عيونك انك اخطيت بحق الزلمة.

$9 \quad$ Swearing

و اللي خلقك إني ما بحب الصيف.

وحياة اللي خلقك انك ما حكيت الصنح.

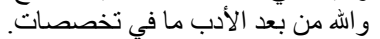

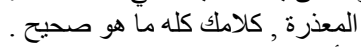

10 Statements of regret

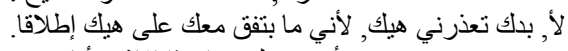

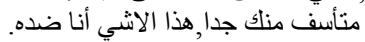

للأسف ,كلامك مش دقيق.

أنا بعارضك في مسألة انه الأدب مش مفيدا.

11 Stating disagreement

هاب العبارة صر احة أنا ما بتفق معها الطاقلاقا.

انا هيك بخالفك في رايك هاظا بقوة.

انا ما بتفقش معالك بهاب السو لافة. 